\title{
THE CONTRIBUTION OF WEANING FOODS TO PROTEIN-ENERGY MALNUTRITION
}

\author{
ANN F. WALKER \\ Department of Food Science and Technology, University of Reading, PO Box 226, \\ Whiteknights, Reading RG6 2AP
}

\section{CONTENTS}

INTRODUCTION

PROTEIN-ENERGY MALNUTRITION AND DIETARY SURVEY DATA . 26

IS THERE A BEST AGE FOR WEANING? . . . . . . . . . . . . . . 29

PROTEIN REQUIREMENTS DURING WEANING . . . . . . . 30

INFECTION AND THE WEANLING'S DILEMMA . . . . . . . . 31

INFANT FEEDING PRACTICES IN THE THIRD WORLD . . . . 32

AGE OF WEANING . . . . . . . . . . . . . . . . . . . . 33

FREQUENCY OF FEEDING . . . . . . . . . . . . . . . . . . . . . 33

INFLUENCE OF MOTHER'S BELIEFS ON FEEDING PRACTICE . . . . . $\quad 34$

AMOUNTS OF BREAST MILK . . . . . . . . . . . . . . . . . 34

PREPARATION OF TRADITIONAL WEANING FOODS . . . . . 35

NUTRITIVE VALUE OF THIRD WORLD WEANING FOODS . . . . 35

PROTEIN CONTENT. . . . . . . . . . . . . . . . . . . . . . 36

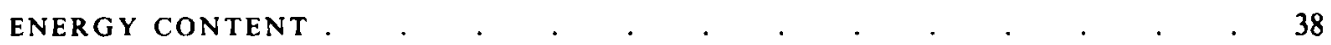

RECOMMENDATIONS FOR THE FORMULATION OF THIRD WORLD

WEANING FOODS . . . . . . . . . . . . 39

METHODS OF REDUCING 'DIETARY BULK'. . . . . . . . . . . $\quad 40$

Dietary components . . . . . . . . . . . . . . . . 40

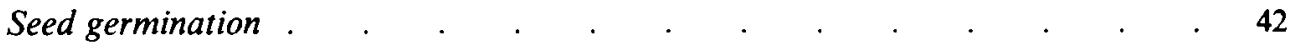

Use of enzyme preparations . . . . . . . . . . . . . . . . . 42

Fermentation . . . . . . . . . . . . . . . . . 42

Extrusion cooking . . . . . . . . . . . . . . . . . . . 43

MONOTONOUS DIETS . . . . . . . . . . . . . . . . 43

CONCLUSION . . . . . . . . . . . . . . . . . . . . 43

REFERENCES . . . . . . . . . . . . . . . . . . . 44

\section{INTRODUCTION}

Hunger and malnutrition continue to cause enormous world-wide human suffering. The most serious nutritional deficiencies are various forms of protein-energy malnutrition (PEM), particularly affecting young children. The United Nations (1987) published the First Report on the World Nutrition Situation, which states that in most parts of the world nutrition has improved over the last 25 years: this is reflected in a reduction in infant and 
child mortality rates. Malnutrition (as indicated by infant and child mortality, children underweight for age and by the relatively new indicator of low birth weight) has remained stable in South America and decreased in Asia and Central America. On the contrary, subSaharan Africa has suffered a long-term decline in food supplies (mainly due to severe drought early in the 1980s) and consequent increased malnutrition. This is reflected in the number of infant and child deaths, which are still rising, in contrast to other regions of the world.

Solutions to many of the underlying problems of undernutrition in the Third World lie outside the professional scope of nutritionists, as they involve economics, politics, food availability and distribution. At a local level, the causes of undernutrition are also complex. They may include (a) inadequate or inappropriate weaning diets or (b) poor nutritional status resulting from disease or illness caused either from improper timing of the introduction of weaning foods or from infections arising from the contamination of them. A clear understanding of the causes of malnutrition is further complicated by uncertainties about nutrient requirements for the weanling and the value of physical indicators of malnutrition.

A subject which deserves more attention from the nutrition fraternity is the provision of adequately nourishing weaning foods. The term weaning is used here as defined by Milla (1986): "the period which commences when solids are introduced and continues until after suckling has been discontinued'. A weaning food is normally a semi-solid food to be used in addition to breast milk and not only to replace it. In most countries the introduction of weaning foods is recommended from about the age of 4 months, when an extra source of energy and other nutrients, such as iron, is required, in addition to those present in human milk.

For several decades following World War II and the description of kwashiorkor by Cecily Williams, it was accepted that infant malnutrition would be greatly alleviated, if not eliminated altogether, by the introduction into the diet of foods high in protein. Evidence that attitudes have changed is seen in the rapid decline in funding for research into proteinquality aspects of foods in the late 1970s and the 1980s. Most contemporary studies on protein quality come from the Third World, where the re-evaluations of human protein and energy requirements (Food and Agriculture Organization/World Health Organization, 1973) have only recently been fully appreciated (Webb, 1989).

Protein requirements of humans during growth are modest compared with other mammalian species. Apart from risk of infection, it is now recognized that a major constraint to the health of infants is an inadequate energy intake. Several factors may conspire to cause malnutrition, including infection, but the problem is compounded by the failure to provide infants in the Third World with weaning foods of adequate energy density. If energy intake is inadequate, then intake of other nutrients, including protein, is likely to be inadequate.

\section{PROTEIN-ENERGY MALNUTRITION AND DIETARY SURVEY DA T A}

Kwashiorkor and marasmus are the extremes of a spectrum of manifestations of PEM, and young children and infants often show symptoms in between the two. The typical appearance of these diseases is well documented. Indeed, the arguments which have led nutritionists to consider lack of energy in the diet as the prime cause of PEM rather than protein are now generally well accepted in developed countries, but they have been slow to permeate even to scientific communities in the Third World. Indeed, even in developed countries this change in view has been slow to filter through to the public consciousness and 
Table 1. Daily energy and protein intakes of weaned infants aged 1-2 years in various countries by individual weighed survey compared with Food and Agriculture Organization/World Health Organization (1973) recommendations. Adapted from Waterlow \& Payne (1975)

\begin{tabular}{lccc}
\hline \hline & \multirow{2}{*}{$\begin{array}{c}\text { No. of } \\
\text { children }\end{array}$} & \multicolumn{2}{c}{ Mean intake (/kg body-wt) } \\
\cline { 3 - 4 } Country & & Protein $(\mathrm{g})^{*}$ & Energy (kJ) \\
& & 1.27 & 440 \\
FAO/WHO (1973) & 30 & $1 \cdot 19$ & 360 \\
Ghana & 28 & 1.16 & 323 \\
Guatemala & 266 & 1.47 & 348 \\
Jamaica & 72 & 1.32 & 295 \\
Polynesia & 54 & 0.61 & 218 \\
Thailand & 124 & 1.28 & 285 \\
Uganda & & & \\
\hline \hline
\end{tabular}

* As fully utilized protein (utilization of protein in actual diet assumed to be $60 \%$ ).

even to be accommodated in standard student texts on nutrition. In a review of this subject, written for educationalists, Webb (1989) made the points summarized in the next three paragraphs.

In the 1960s kwashiorkor was ascribed to protein deficiency, while marasmus was considered to be caused by a lack of energy in the diet. It is not usual these days to regard the two diseases as so separate. In the 1960s kwashiorkor was regarded as the predominating manifestation of PEM, and high-protein supplements were promoted through aid programmes in an attempt to bridge the 'protein ' gap. It is now known that marasmus is equally, if not more, common. One basic tenet of the protein gap hypothesis was that the protein requirement of infants (which can be expressed as the percentage of dietary protein energy: total dietary energy ratio; PE ratio) was high. However, the PE ratio of $6 \%$ for human milk is very low when compared to other faster-growing mammals (cf. the value of $24 \%$ for sheep's milk).

Against the background of the publication of FAO/WHO (1973), Energy and Protein Requirements, which gave lower recommended daily amounts (RDA) for protein than had been previously recommended internationally, other evidence was coming forward. In India, Gopalan (1968) concluded from a survey of children, including those with kwashiorkor and marasmus, that the only difference in the diets of the two groups was a slightly greater restriction of energy and protein in the kwashiorkor group, but no difference in the PE ratio. This finding indicated that individual requirements played an important role in the manifestation of PEM. In addition, dietary survey findings from poor communities of the Third World published by Waterlow \& Payne (1975) were very revealing (Table 1), as they showed that energy intake was much lower than RDA in all the countries studied. This is important, as lack of energy in the diet jeopardizes the use of protein for growth and maintenance. If the energy intake from other sources is inadequate, then protein is used as an energy source and not for its primary function of growth and maintenance.

The survey findings of Waterlow \& Payne (1975) have since been supported by others. For example, Van Steenbergen et al. (1978) reported that although protein intake was satisfactory in Kenya at all ages of weaning, the average energy obtained from the diet was 86,90 and $96 \%$ of RDA at $0-6,7-18$ and 19-36 months respectively. Children were small 
for age, and $10 \%$ were moderately malnourished. Grossly inadequate energy intake, as well as low protein intake, of infants $(<1$ year) were reported in an urban, low-income area of Ibadan, Nigeria by Akinyele \& Omotola (1986). Between 30 and $50 \%$ of the infants suffered varying degrees of malnutrition, whilst about $1 \%$ were wasted and stunted. These authors recognized that an adequate protein intake is not of much value when there is inadequate energy consumption.

Over recent years, most organizations supplying food aid have aimed to increase the intake of energy in the diet. To do this, it is important to take account of the acceptability of foods, as people will not consume sufficient food to meet their energy requirements if the food is unpalatable, unfamiliar or monotonous. If energy intake is adequate, then most staples in the diet, e.g. wheat or rice, will provide enough protein. The main exceptions to this are the tropical crops, cassava, plantain and sweet potato, which have a very low protein content and, thus, care should be taken to supplement them with other sources of protein.

In the present review, deficiency of vitamins and minerals in PEM is not dealt with in depth, because most studies have placed emphasis on intakes of energy and protein. However, PEM is increasingly being regarded not merely as a manifestation of deficiency of energy and protein, but of many nutrients. Golden \& Ramdath (1986) have postulated a relationship between reduced antioxidant nutrient status and the development of kwashiorkor. Particular interest is focused on the intakes not only of vitamins $A, C$ and $E$ and $\beta$-carotene, but also on dietary selenium, manganese, copper and zinc, which are essential components of key enzymes involved in antioxidant pathways responsible for minimizing free-radical attack (Ramdath \& Golden, 1989).

Golden \& Ramdath (1986) concluded that in the development of kwashiorkor, free radicals are formed, often as part of the body's immune response to infection. In addition, high levels of iron may also promote free-radical formation (see below). Normally, these free radicals are scavenged and dissipated through various pathways involving the antioxidant nutrients. Golden \& Ramdath (1986) proposed that kwashiorkor develops when there is a relative deficiency in the protective pathways due to nutrient deficiency.

$\mathrm{Zn}$ has been shown to be a limiting factor in the growth of severely malnourished infants (Hambidge, 1986), with premature infants being most affected. While low levels of both $\mathrm{Zn}$ and $\mathrm{Fe}$ in the blood may hamper the multiplication of pathogenic organisms in the body and, therefore, be of advantage, deficiency of both of these minerals reduces the immune response (Chesters \& Arthur, 1988). Fe status in malnutrition may be particularly important, with both low and high levels compromising good health. Ramdath \& Golden (1989), in a detailed review covering non-haematological aspects of Fe nutrition, conclude that excessively high levels of $\mathrm{Fe}$ (in Fe stores, not in plasma) may act as foci for the initiation of free-radical reactions, leading to lipid peroxidation, which can cause toxic damage to tissues and the symptoms of kwashiorkor. Indeed, they state that recently published evidence indicates that while levels of transferrin and haemoglobin are low in kwashiorkor, stores of ferritin are high. Under conditions of malnutrition, $\mathrm{Fe}$ in the bloodstream may be less well contained and, therefore, able more easily to exert its properties of initiating free radical formation.

Vitamin $\mathrm{A}$ is one nutrient which has been specifically studied in malnutrition, because of the susceptibility of infants and children with PEM to xerophthalmia. In a review of vitamin A, immunity and infection, Tomkins \& Hussey (1989) comment that children with mild xerophthalmia due to deficiency of vitamin $A$ are also more likely to develop diarrhoea and respiratory tract infections than children without vitamin A deficiency. They conclude that children who are compromised with respect to antioxidant status have been shown to be more prone to infection. While involvement in antioxidant activity is not 
unique to vitamin $\mathrm{A}$, more is known about this vitamin in conditions of severe malnutrition, because of its deficiency manifesting as xerophthalmia. Intervention studies using supplementary vitamin A have shown reduction in mortality, especially among lowbirth-weight infants who have deficient stores of vitamin $\mathrm{A}$.

\section{IS THERE A BEST AGE FOR WEANING?}

Human milk is regarded as the most suitable food for the newborn infant. It satisfies all nutrient requirements and, in addition, provides various factors which protect the infant against attack from pathogens. Supplementary food is required when the energy requirement of the infant exceeds the amount provided by maternal milk. The age at which this point is reached is dependent on (a) milk quantity and quality, (b) size and requirement of the infant and (c) other factors, such as health of the mother and baby.

The identification of the point in lactation at which milk no longer provides energy for the infant is confounded by the validity of the RDA, against which energy intakes are compared. There are indications that RDA for energy over the weaning period are set too high. For example, Persson et al. (1984) interviewed seventy-six mothers in Sweden to obtain a 24 h dietary recall on their 6-month-old weanlings, for whom 'follow up' formulas contributed $57 \%$ to total energy intake. Despite the mean total daily energy intake of the infants being only $75 \%$ of the RDA, physical growth was in accordance with international standards. Other studies at Cambridge showed that from 2 to 8 months of age, standard rates of infant growth were being achieved on energy intakes substantially lower than current RDA (Whitehead, 1985a,b). These studies indicate that the current recommendations for energy intake in infancy are higher than the true need for healthy growth, particularly at about 6 months of age.

As human milk production appears to reach a maximum between 4 and 6 months after birth (Van Steenbergen et al. 1978), these findings have an important bearing on the length of time human milk can be expected to satisfy infant requirements alone, without the introduction of weaning foods. If they are generally applicable, the length of time that human milk is adequate as the only source of energy supply can be increased to 4 months (more in line with current recommendations, e.g. Department of Health and Social Security, 1988) from an estimated 2 months only.

Not only have the RDA been subjected to further scrutiny in recent years, but so have the growth standards. This adds a further difficulty in the determination of the point in lactation when breast milk is no longer adequate. Evidence that breast-fed infants grow more slowly than infants fed formula milks and solids has been reviewed (Anon. 1986). The review suggested that the smaller size of breast-fed babies than formula-fed babies is not a cause for concern and is a 'natural' occurrence. This is important in Third World situations, where this point should be taken into consideration before concluding that breast-fed children are malnourished. For example, Victora et al. (1984) studied 802 children aged 12-35 months in Southern Brazil. The prevalence of malnutrition (as indicated by low weight- and length-for-age, and weight-for-length) was lower in those children breast-fed for 3-6 months, but higher if breast-feeding was continued beyond this age.

The equivocal value of using physiological indicators of gut function in early life to predict the age of weaning is reviewed by Lebenthal (1985). While in the neonate there are a number of digestive enzymes whose activity is low, there always remains the possibility that increased enzyme activity may be substrate induced. Starch is not present in milk, but is a common ingredient in weaning foods, so the activity of digestive amylase (EC 3.2.1 .1) could be particularly important. While information on babies is limited, comparisons can 
be drawn with other mammals. In pigs, there is a specific period at the age of 3-4 weeks when digestive enzyme activities are markedly increased, including amylase (Corring et al. 1978). However, on the question of substrate induction, Corring et al. (1972) found no change in age of the appearance of amylase activity in rabbits weaned suddenly onto a highstarch diet at $21 \mathrm{~d}$, compared with $30 \mathrm{~d}$. These authors concluded that in the rabbit, feed is not a factor stimulating pancreatic enzyme development. In humans, pancreatic amylase is not produced at all in the neonate; indeed, the late appearance of this enzyme (not fully active until 6-9 months of age, according to Lebenthal, 1985) may contra-indicate early introduction of starches into the diet.

Lebenthal (1985) suggests that the early introduction of solids high in starch may produce symptoms similar to infectious gastroenteritis, because low levels of pancreatic amylase lead to poor digestion and absorption. He reports that chronic, non-specific diarrhoea in infancy related to early introduction of starchy foods low in fat has been described. He goes further to suggest that malnutrition and disease (see p. 7) may hinder the development of small-intestine mucosal enzyme activity and pancreatic enzymes.

From the evidence presented here, it would seem that the precise age for the introduction of weaning foods should not be calculated from present RDA, which may be set too high for the weaning period. However, gut function changes with age indicate that the early introduction of weaning foods, particularly those containing starch, is inappropriate. Waterlow \& Thomson (1979) concluded that breast milk fails to cover the energy needs of many infants in the Third World after about 3 months of age, when growth begins to fall off. They state that it is not clear whether cessation of growth is due to insufficient food or infections caused by the introduction of supplementary foods. These authors concluded that until more information was available, advice regarding the length of time for exclusive breast-feeding should not be stated too dogmatically. In view of the present uncertainty, the approach taken by the DHSS (1988) would seem best: 'The age at which individual infants should be offered solid food varies. Very few infants will require solid foods before the age of three months but the majority should be offered a mixed diet not later than the age of six months.'

\section{PROTEIN REQUIREMENTS DURING WEANING}

While the intake of high-protein formulas is well recognized as a risk to health for the neonate, it has been assumed by most authorities that by the age of 4 or 6 months higher levels of protein can be tolerated by the baby without harm. Indeed, it has been a general practice in the industrialized world to manufacture infant follow-up formulas with higher protein contents than breast milk for safety reasons, even though the optimal ratio between fat, carbohydrate and protein is not known (Persson et al. 1984). Some recent work (summarized in the next two paragraphs) provides metabolic indicators that the protein levels of these milks may be greater than requirements, although there is no indication that this is harmful.

Axelsson et al. (1987a,b, $1988 a)$ measured the growth and metabolic responses of thirty weanlings (4-6 months of age) to feeding regimens containing different levels of protein fed on an ad lib. basis as shown in Table 2 . The follow-up formulas used were milk-based and similar to those in common use for infants in Scandinavia. Formula-fed infants had significantly higher protein and energy intakes than breast-fed groups. However, there were no significant differences in the rate of growth or weight gain. Preprandial plasma amino acid levels were higher in formula-fed infants, as were serum urea and total nitrogen in the urine. The authors concluded that formulas in common use during weaning provide protein in greater amounts than required for growth and maintenance. 
Table 2. Protein and energy intakes of healthy weanlings aged 4-6 months on two high-protein follow-up formulas compared with human milk. Values from Axelsson et al. (1987a, b, $1988 \mathrm{a})$.

(Mean values for ten weanlings/group)

\begin{tabular}{lccc}
\hline \hline & F1 & F2 & HM \\
\hline Protein content $(\mathrm{g} / \mathrm{l})$ & 19 & 29 & 9.6 \\
Energy content $(\mathrm{kJ} / \mathrm{l})$ & 3020 & 2900 & 2730 \\
PE ratio \% & 10.5 & 16.8 & 5.9 \\
Energy intake (kJ/kg per d) & 424 & 395 & 336 \\
Protein intake (g/kg per d) & 2.6 & 3.6 & 1.3 \\
\hline \hline
\end{tabular}

F, follow-up formula; HM, human milk.

In a later experiment Axelsson et al. (1988b) studied twenty infants of 4-6 months fed with either a low-protein formula containing $13 \mathrm{~g}$ protein/l (PE ratio $7.2 \%$ ), or a highprotein formula containing $18 \mathrm{~g}$ protein $/ 1$ (PE ratio of $10 \%$ ). These formulas were isoenergetic (3.01 MJ (720 kcal)/l). Ten breast-fed infants were used as controls. In contrast to the previous experiment (but in keeping with previous reports: Anon. 1986), breast-fed infants and low-protein-formula groups were lighter than high-protein-formula-fed infants. Metabolic indices (blood amino acid and urea levels) of the low-protein-formula group were similar to those of the breast-milk group. Axelsson et al. (1988 b) concluded that consumption of low-protein follow-up milks by infants would allow metabolic indices to match more closely those of their breast-fed counterparts.

\section{INFECTION AND THE WEANLING'S DILEMMA}

The term 'the weanling's dilemma' was coined by Rowland et al. (1978) to describe the difficult choice to be made in the interest of the health of the weanling in the Third World. Human milk does not provide enough energy to meet requirements of the infant of about 4-6 months of age. Therefore, there is risk of malnutrition, unless weaning foods are introduced, but this puts the infant at a high risk of infection, including diarrhoea.

The importance of infection as an aetiological factor for PEM cannot be overemphasized. Indeed, Whitehead (1989) points out that much malnutrition in the Third World is secondary to poverty, poor hygiene and contaminated food. Of all the infections which can affect the health of an infant in the Third World, those causing diarrhoea are the most important. Rowland et al. (1977) concluded that in the absence of infections, dietary intakes in The Gambia were such that infant growth would have been fairly normal at most times of the year. Only in certain months of the year, when food supplies were short, was primary dietary deficiency the principal problem, rather than diarrhoea.

There is some evidence from the Third World that infants suffer less infections if they are breast-fed and that this protection extends to other types of infection as well as those affecting the gut. Breast-feeding appears to protect growth even when infections do occur (Hoyle et al. 1980). Thus, Victora et al. (1987) studied infants in an urban area of Southern Brazil. Compared with infants who were breast-fed with no milk supplements, those completely weaned had 14.2 and 3.6 times the risk of death from diarrhoea and respiratory infections. Part-weaning was associated with corresponding relative risks of 4.2 and 1.6 . 
Cow's and formula milk seemed to be equally hazardous. For deaths due to diarrhoea, the increased risk associated with not breast-feeding was greatest in the first 2 months of life.

Early weaning has been shown to be particularly hazardous to the infant. Elegbe \& Ojofeitimi (1984) carried out microbiological examination of stools of forty-five infants aged between 1 and 18 months in Nigeria. Children who were not subjected to early weaning and supplementary foods had much lower incidence of pathogenic bacteria. Rowland (1986) laments the continuing high level of morbidity and mortality of infants from diarrhoeal disease. He concludes that there has been very little attempt to improve weaning food preparation techniques in the Third World, particularly in respect of consistency and shelf-life.

Considering the high risk to health of so many infants, it is remarkable that so few reports of studies on the microbiological quality of weaning foods in Third World countries have appeared in the 1980 s. Those reports that have appeared make rather disturbing reading, as summarized in the next paragraph.

Black et al. (1981) reported that $41 \%$ of traditional weaning foods in rural Bangladesh were contaminated with Escherichia coli (the presence of which was used as an indicator of faecal contamination). They found that this was also true of $50 \%$ of drinking-water specimens. These organisms were especially present in high numbers in stored, cooked foods kept at high environmental temperatures. Dettwyler (1987), working in Mali, reported that women feeding their babies weaning food or formula by bottle did not boil the water or the bottle. According to Rowland et al. (1978), weaning gruels in The Gambia may only be subjected to token boiling during preparation, as prolonged boiling results in a mixture which is too thick for young infants. The preparation is time-consuming and tedious and, therefore, it is common practice to prepare large amounts for use throughout the day, resulting in a portion of the gruel being kept at high ambient temperatures for over $12 \mathrm{~h}$. These practices provide ample opportunity for pathogen contamination and proliferation. It is perhaps not surprising, therefore, to find greater contamination of weaning foods than foods prepared for adults (Black et al. 1989).

Milla (1986) concludes that one of the main reasons why the first 6 months of life is such a vulnerable time is because of the state of development of the gut. Not only are the digestive and absorptive mechanisms immature, but so are the gut defensive systems, both immune and non-immune. Time is needed for the development of protection from enteric infection and from entry of foreign proteins. He suggests that premature weaning may overload the digestive and absorptive systems and lead to sensitization to food antigens. These factors, together with ingestion of foods having a high bacterial load, lead to high risk of diarrhoea.

\section{INFANT FEEDING PRACTICES IN THE THIRD WORLD}

Although there are reports (Whichelow, 1982; Jones, 1987) that the commencement of weaning in industrialized countries is tending to be delayed in response to authoritative advice such as that of the DHSS (1988), the reverse may be the case in the Third World. Traditional weaning foods or gruels may be introduced as a supplement to breast milk from a very early age, often well before 4 months of age, even though breast feeding may be continued for as long as 18-24 months and beyond. However, infant feeding practices vary considerably (Dimond \& Ashworth, 1987; p. 9). One advantage that mothers in the Third World have over their counterparts in the richer countries is that women in many parts of the Third World are conditioned by their culture to expect a successful lactation. 


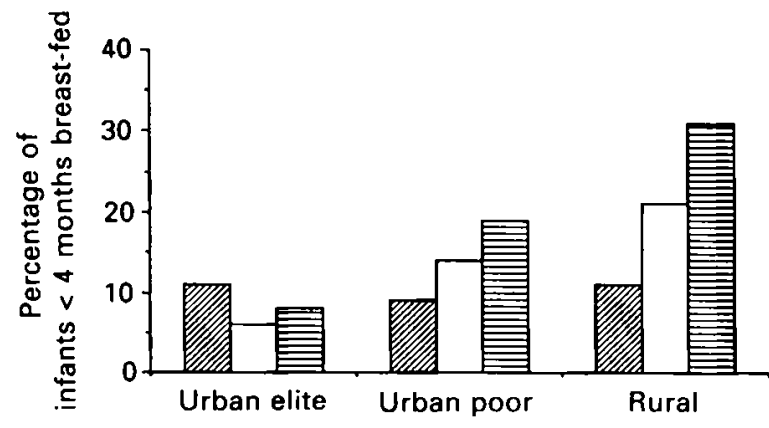

Fig. 1. The percentage of infants below 4 months of age who are exclusively breast-fed in three Third World countries, according to socio-economic group. (Ø), Malaysia ; ( $\square$ ), Kenya ; (目) Mexico. Values from Dimond \& Ashworth (1987)

\section{AGE OF WEANING}

Dimond \& Ashworth (1987) conducted a detailed study of 6149 mothers in Kenya, Mexico and Malaysia, and showed that in addition to considerable differences in Third World weaning practices there were also urban and rural differences in all these countries (see Fig. 1).

An outstanding feature of the study was that while most urban and rural Kenyan mothers breast-fed infants for at least 12 months, regardless of social class, only a minority breast-fed for longer than 6 months in Mexico and Malaysia. A finding of considerable concern was that even in the first month, over $50 \%$ of infants in all groups were supplemented with milk and/or other food, except in Kenya, but even there the majority were given water and/or fruit juice. If nothing else, this would allow the introduction of pathogenic organisms from non-potable water sources. Dimond \& Ashworth (1987) considered that attempts to stop mothers in the Third World introducing weaning foods early in life have failed. Paid employment of mothers has a very important influence on this, and is likely to continue to impinge on family life. These authors discuss the implications of these findings on the recent tendency towards discouraging the use of infant formulas in the Third World, when something even less suitable (cow's milk or cereals) might be offered to the infant at this vulnerable age by working mothers.

Van Steenbergen et al. (1978) made a comprehensive study of 183 children of the Machakos district of Kenya, and emphasized many points common to infant feeding practices in Third World countries. Some of these points are mentioned later in the present review. At the time of the study, mothers in the Machakos district had, on average, a good nutritional status. The study involved weighed measurement of the intake of breast milk and additional foods by the infants over a $4 \mathrm{~d}$ period. Nutritional status was measured by weight and height measurements and a clinical assessment was made of general health. The pattern of infant feeding is seen in Fig. 2. A large proportion of infants were exclusively breast-fed to 2 months of age, with cessation of breast-feeding occurring at about 18 months. Children were generally breast-fed for 12-18 months or longer; additional foods (milk, and thin, watery cereal porridge) were introduced at about 4 months of age and a maize-beans dish given about 24 months.

\section{FREQUENCY OF FEEDING}

At weaning, because of the small capacity of the infant's stomach and the low energy 


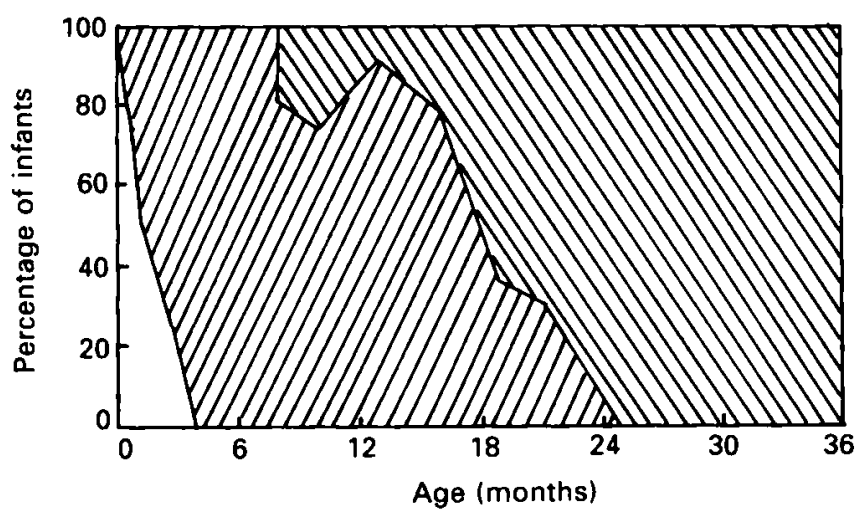

Fig. 2. Sequence of breast-feeding and introduction of weaning foods in the Machakos district of Kenya. $(\square)$, Exclusively breast-fed; $(\square)$, breast-feeding and other foods; $(\mathbb{Q})$, completely weaned. From Van Steenbergen et al. (1978).

density of weaning foods, it is necessary that infants have more frequent meals than adults. The frequency of feeding various foods to weanlings of various ages in Kenya showed a maximum of four meals/d at 7-12 months. If a weaning food is low in energy density, even increasing feed frequency may not raise the total food intake sufficiently to meet requirements. Thus, Rutishauser \& Frood (1973) showed in Uganda that infants fed on traditional weaning diets had insufficient energy intakes, when fed ad lib. as often as five times daily.

It might be supposed that the introduction of weaning foods leads to a reduction in breast-feeding. However, in Mali, where infants are breast-fed well past the first year of life, the introduction of solid foods has little impact on breast-feeding frequency (Dettwyler, 1987).

\section{INFLUENCE OF MOTHER'S BELIEFS ON FEEDING PRACTICE}

Although many guidelines (such as the DHSS, 1988) recommend that infants should be weaned by about 4-6 months, in many Third World countries mothers' beliefs do not coincide with this view. In Ecuador, for example, 8.8 months is the mean age to begin supplementing breast milk and 16 months is regarded as best age to finish weaning (Pigott \& Kolasa, 1983). A similar belief prevails in Mali (Dettwyler, 1986).

In many studies throughout the world, it is clear that mothers are aware of the importance of breast-feeding. However, there may be discrepancy between actual feeding practices and mothers' views on what these practices should be. One influencing factor in Nigeria appeared to be the great pressure on mothers to spend time augmenting the family income at the expense of caring adequately for their children (Anyanwu \& Enwonwu, 1985). Mothers in Mali (Dettwyler, 1986) felt strongly that infants should be weaned when the mother becomes pregnant again. Despite these beliefs, many siblings were born only 4 or 5 months after the older children had been weaned.

\section{AMOUNTS OF BREAST MILK}

The average breast-milk intake of newborn babies in the Machakos district of Kenya was found to be equivalent to that of well-nourished mothers in Europe and North America 
Table 3. Non-breast-milk foods in diet of infants in the Machakos district of Kenya (average intake, $\mathrm{g} / \mathrm{d}$ ). Adapted from Van Steenbergen et al. (1978).

\begin{tabular}{|c|c|c|c|c|c|}
\hline \multirow[b]{2}{*}{ Food } & \multicolumn{5}{|c|}{ Age (months) } \\
\hline & $0-6$ & $7-12$ & 1318 & $19-24$ & 2536 \\
\hline Cow's milk & 120 & 120 & 75 & 140 & 130 \\
\hline Maize & 5 & 70 & 100 & 160 & 190 \\
\hline Tubers & 0 & 15 & 15 & 60 & 60 \\
\hline Legumes & 0 & 0 & 5 & 20 & 30 \\
\hline Vegetables & 0 & 20 & 30 & 45 & 50 \\
\hline Fruits & 0 & 10 & 15 & 30 & 25 \\
\hline Fat & 0 & l & 2 & 2 & 2 \\
\hline Sugar & 1 & 4 & 7 & 7 & 10 \\
\hline
\end{tabular}

(Van Steenbergen et al. 1978), with a mean volume of $675 \mathrm{ml} / \mathrm{d}$. However, between 4 and 6 months of age higher infant intakes than the mean of $555 \mathrm{ml}$ reported in Kenya have been reported from Swedish mothers and West African mothers, although levels in Kenya $(487 \mathrm{ml} / \mathrm{d})$ were similar to those in Mexico and India. Although there is little information on breast-milk production from affluent societies for babies more than 7 months, yields at this age in Kenya were comparable with those reported from other Third World countries.

\section{PREPARATION OF TRADITIONAL WEANING FOODS}

Traditionally, weaning foods in many Third World countries are prepared from flours of starchy staple foods. On heating these with water, the starch gelatinizes, forming thick pastes of low solids concentration. McCrae \& Paul (1979) discuss the preparation of infant gruels in The Gambia, where, after flour preparation, there are several methods used for the preparation of gruels. The most common is to add the flour to cold water and mix to a paste, and then to add the paste to boiling water, stirring all the time and then to bring the mixture back to the boil. Weaning gruels may consist of staple with or without sugar, salt, sour milk, baobab juice and groundnuts (McCrae \& Paul, 1979; Hudson et al. 1980). Sugar is by far the most important addition to weaning foods and is commonly added to improve the flavour and to encourage infants to eat. Only rarely are fish or palm oil added (Barrell \& Rowland, 1979). Table 3 shows the intake of various foods by age group in the Machakos district of Kenya. The first additional foods usually include a thin maize porridge fed by bottle. At about 1 year of age, a solid maize dish is introduced, and after weaning a maize-bean dish is added. As in The Gambia, fat was added infrequently to the diet.

\section{NUTRITIVE VALUE OF THIRD WORLD WEANING FOODS}

Van Steenbergen et al. (1978) attributed deficiency in growth in infants in Kenya to the early decline of breast-milk yields and the supply of a watery porridge, together with exposure to childhood infections. An increase in food energy intake was advised. Even in industrialized countries such as Holland, the growth of children can be compromised by low-energy cereal foods. Thus, growth of babies on macrobiotic diets has been reported as being seriously affected (Dagnelie et al. 1989). (A macrobiotic diet is part of a spiritual philosophy. The diet consists predominantly or even exclusively of whole-grain cereals, 
sometimes uncooked.) Weaning foods introduced to supplement human milk should have sufficient energy and protein to cover an infant's requirements. Satisfying energy needs is critical, because if energy intake is insufficient, then protein will be used as an energy source and will not be available for growth and maintenance.

\section{PROTEIN CONTENT}

Jansen \& Harper $(1980 b)$ commented that weaning foods used in supplementary feeding programmes typically contain $170-200 \mathrm{~g}$ protein $/ \mathrm{kg}$, or higher and that these levels were established at a time when a high protein intake was considered to be more important than it is today. The use of energy and protein RDA of FAO/WHO (1973) led to a recommendation of a $\mathrm{PE}$ ratio percentage of 6.6 , which is a value largely supported by $\mathrm{PE}$ ratio percentages calculated from Food and Agriculture Organization/World Health Organization/ United Nations University (1985) values (6.0-7.0 for infants of 12-6 months respectively). These values compare favourably with breast milk, which is as expected. Despite these recommendations, few have followed such guidelines in formulating Third World weaning foods in the 1980s. Indeed, it is rare to find reports on weaning foods with $\mathrm{PE}$ ratio percentages as low as these.

The report of FAO/WHO/UNU (1985) warns of the improper application of the PE ratio percentage, and in particular the use of a reference $P E$ ratio percentage, as this will depend on individual energy and protein requirements. However, values are unlikely to vary greatly from breast milk for proteins which are fully utilized, and this approach is very useful when comparing total diets. Following guidance of FAO/WHO/UNU (1985), the increased protein requirement of the infant can be calculated if the protein of the weaning food is not fully utilized. Thus, for a protein with an amino acid score of 70 and a digestibility of 85 , the PE ratio percentage required by the infant (assuming the weaning food to be the only item of the diet and eaten in sufficient quantity to cover energy requirements) would be nearer to 10-11. This higher level of protein would be advisable for weaning foods entirely of vegetable origin, particularly those used late in weaning, when breast-milk supplies are coming to an end.

Table 4 shows that some of those weaning food formulations which have been advocated in or for the Third World have unnecessarily high levels of protein. While high levels of protein may not be damaging to the older infant, they are not required for growth and, therefore, are broken down and used as an energy source, as shown by the metabolic indicators already discussed (Axelsson et al. 1987a, b). At the least this constitutes a waste of resources, and results in the production of weaning foods which are too expensive for rural mothers to purchase for their infants.

In view of the realization that protein deficiency is not, in general, of prime importance in the aetiology of PEM, perhaps it is of some consolation to find that in the 1980 s the number of papers describing attempts to supplement weaning foods with amino acids has greatly declined. A scan of the recent literature revealed only two papers, those of Del Valle et al. (1981) and Vargas et al. (1985). The former reported the weight-gain improvement of malnourished infants fed on a soya-bean, oat, sucrose mixture fortified with methionine. The latter reported the improvement in protein quality of a soya-bean, rice, banana weaning food with added lysine.

Most reports in Table 4 show the quality of weaning foods (usually assessed by animal assay) to be as good, or nearly as good, as casein. As no upward adjustment in protein requirements needs to be made for proteins of good quality, these findings further emphasize the lack of requirement for PE ratio percentages as high as 10-11. In Table 4, 


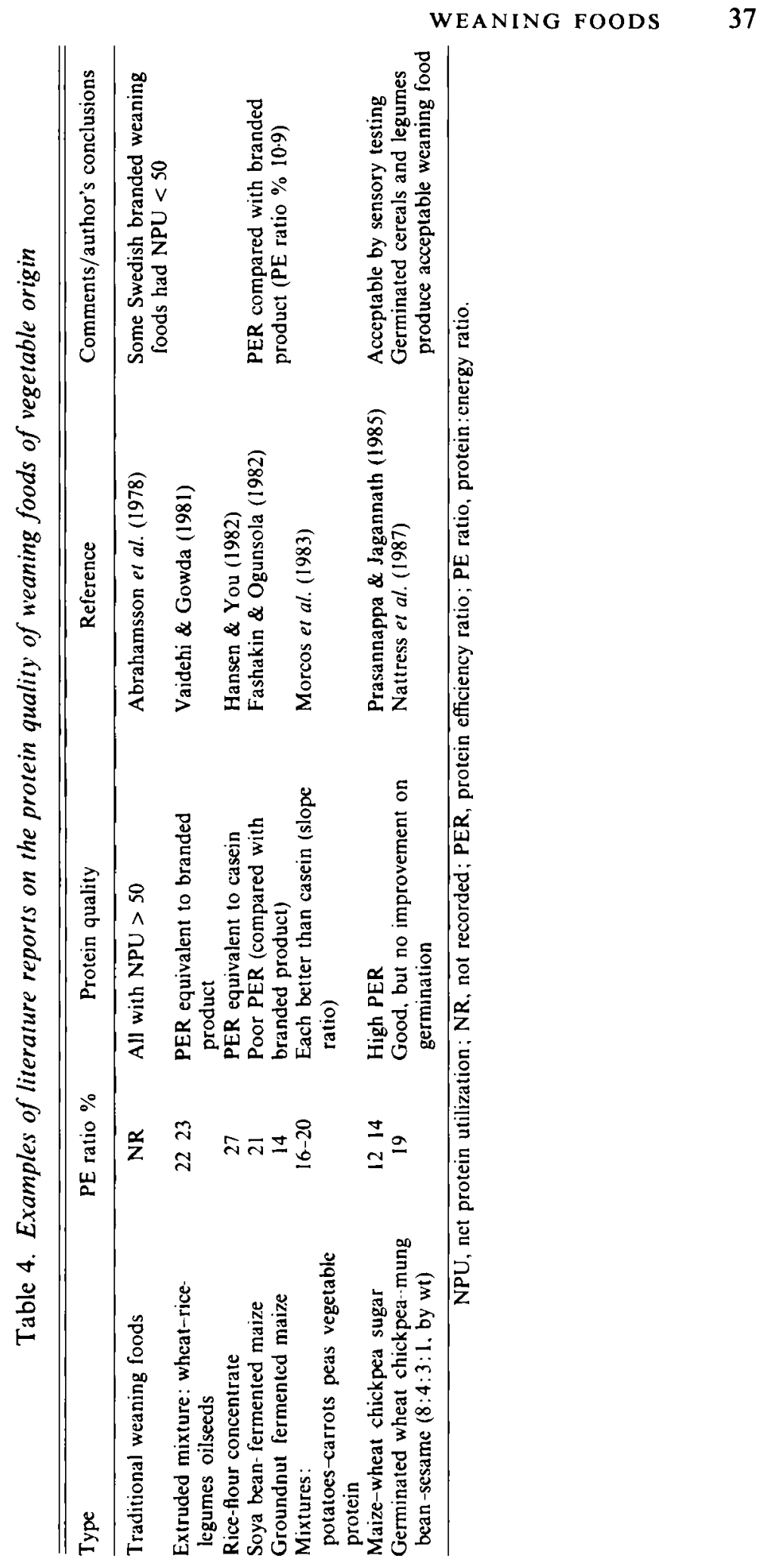


only Fashakin \& Ogunsola (1982) report poor protein quality of a traditional weaning food (maize-soya-bean and maize-groundnut mixtures) when compared with a commercial weaning food. These authors concluded that the amino acid patterns of these mixtures were not sufficiently complementary and that other protein sources should be added to raise the quality.

\section{ENERGY CONTENT}

Akinyele \& Omotola (1986) concluded from their studies in Ibadan, Nigeria, that deficient intakes of energy and protein occurred irrespective of whether infants were being breastfed or weaned. These authors laid blame on the traditional weaning foods in Nigeria, which were 'bulky' and limited the infant's ability to eat enough (the word bulky is used in the literature to refer to a weaning food of high viscosity, but low energy density; these characteristics are mostly due to high water-binding properties of the constituents of the food). Van Steenbergen et al. (1978) also concluded from their studies in Kenya that an increase in energy intake was essential and that it could be achieved by earlier introduction of the thick porridge dish, especially if fat was added in the preparation. While the latter point is important, it is unlikely that a young baby would accept a thick food early in weaning.

The viscosity or consistency of a food is critical during weaning. An infant needs a gradual transition from fluid to solid foods over this period, to allow the development of feeding skills. Early in weaning, the infant will reject very viscous foods by spitting them out. A typical Third World weaning food given at an acceptable consistency for a young infant (for example, a gruel prepared from millet flour containing $100 \mathrm{~g}$ solids/l) would have a low energy density of $1200 \mathrm{~kJ} / \mathrm{kg}$, compared with the much higher value of $2860 \mathrm{~kJ} / \mathrm{kg}$ for breast milk. A typical, prepared, UK weaning food can have an energy density as high as $5980 \mathrm{~kJ} / \mathrm{kg}$.

The factors limiting energy intake of an infant weaned onto a low-energy gruel are the volume that the child can consume at one time and the frequency of feeding. Although information is scarce, the capacity of a weaning infant for artificial milks has been estimated to be as low as $200 \mathrm{ml} / \mathrm{meal}$ by Buffa (1969) and $300 \mathrm{ml} / \mathrm{meal}$ by Abrahamsson et al. (1978).

Ljungqvist et al. (1981) describe the problem of low-energy-density weaning foods caused by bulky gruels whose contribution to PEM is emphasized by a simple calculation : if a gruel contained $100 \mathrm{~g}$ cereal flour/l (often gruels contain much lower levels of solids), then an infant may only consume $20 \mathrm{~g}$ flour at each feed of $200 \mathrm{ml}$. Many infants in the developing world may only be fed two or three times daily, so the maximum quantity of flour eaten would be $60 \mathrm{~g} / \mathrm{d}$. Assuming that the average energy content of the flour is $14640 \mathrm{~kJ} / \mathrm{kg}$ (Hudson et al. 1980) and the protein content is approximately $80 \mathrm{~g} / \mathrm{kg}$, then an infant eating only gruel would be receiving $878 \mathrm{~kJ} / \mathrm{d}$ and $4.8 \mathrm{~g}$ protein $/ \mathrm{d}$.

At 6 months of age, RDA for energy and protein for an infant of $7 \mathrm{~kg}$ would be 3220 $\mathrm{kJ}$ and $13.0 \mathrm{~g}$ (FAO/WHO, 1973). Thus, a diet consisting only of traditional cereal gruel would be very inadequate for an infant. While these foods present the greatest risk to those infants who are abruptly weaned and then receive no breast milk, they are also a danger for infants who continue to be breast-fed, as large quantities of food of low energy density will lower capacity for breast milk.

In some situations in the Third World, even weaning foods which are high in protein may have a low energy density, when prepared ready for consumption by the infant (Hellstrom et al. 1981). Although relatively low volumes $(400-740 \mathrm{ml} / \mathrm{d})$ would cover protein needs of a 1 year old, much higher (and more variable) volumes are required to cover energy requirements $(730-1440 \mathrm{ml} / \mathrm{d})$, which are beyond the capacity of most infants. 
Few of those who study weaning food formulation examine the energy densities of the foods at a consistency acceptable to infants. The most important food constituents determining dietary bulk of weaning foods are starch and water. When starch is heated in water gelatinization occurs with an increase in apparent viscosity. Cooling such a hot starch paste of a high enough concentration leads to the formation of a gel with a continuous, three-dimensional network of swollen starch granules entrapping water.

Although viscosity measurements are thought to yield the most useful information on the consistency of weaning foods, viscosity values associated with feed rejection in infants have not been reported nor have values causing significant alterations in gastric emptying rate, which might influence feed frequency. Mosha \& Svanberg (1983) stated that apparent viscosities suitable for feeding children (unspecified age) ranged from 1000 to $3000 \mathrm{mPa} \mathrm{s}$. As the flow properties of starchy weaning foods are complex, the shear conditions prevailing under physiological conditions must first be identified and procedures standardized, before meaningful viscosity measurements may be made. Care is needed in the use and interpretation of viscosity measurement applied to weaning foods, as they are thixotropic (thin on application of shear; Walker \& Pavitt, 1989).

\section{RECOMMENDATIONS FOR THE FORMULATION OF THIRD WORLD WEANING FOODS}

Considering the problems caused by traditional weaning foods in the Third World, it is perhaps surprising that there is a lack of readily available advice on the formulation and preparation of weaning foods. In addition to the Manual on Feeding Infants and Young Children (Cameron \& Hofvander, 1983), a recent comprehensive guide is that of the Royal Tropical Institute, Amsterdam (1987). The authors comment that a number of projects were established in Africa in the 1970s to manufacture weaning foods for local consumption, and almost without exception they have failed. Often the levels of management required for such projects were unrealistically high and sometimes imported raw materials were needed, which required hard currency. The resulting weaning foods were too expensive except for the elite.

Royal Tropical Institute, Amsterdam (1987) recommend an appropriate intermediate technology which is adapted to local conditions, for the small-scale, batch manufacture of locally acceptable weaning foods. Use is made of traditional foods obtained at reasonable prices. The recommended ingredients and the approximate final nutritional composition are given in Table 5. The guidelines include processing details, marketing methods and building requirements. Estimated costs to consumer should be about twice the cost of raw materials, which allows for a small profit margin. The final weaning food is meant to be supplemented with human milk or other foods and, therefore, no vitamin and mineral mix is added.

Third World weaning foods are largely of vegetarian origin. Even in the industrialized world, it is now recognized that weaning children onto entirely or predominantly vegetarian foods may cause nutritional problems. In a special report on vegetarian weaning by the Nutrition Standing Committee of the British Paediatric Association (1988), it was recommended that special attention be paid to the low energy density of many vegetarian foods, caused by the low fat and high fibre content, as small infants may have difficulty consuming the necessary volume of diet to achieve adequate energy intake. It was recommended that: (1) weanlings should be fed frequently with at least four meals daily; (2) the energy density of foods should be increased by serving cereals as thick, rather than thin, porridge and/or adding fats to cereal meals; (3) satiating appetite before a meal with low-energy juices should be avoided. 
Table 5. Recommended composition of a Third World weaning food $(/ \mathrm{kg})$. Adapted from Royal Tropical Institute, Amsterdam (1987)

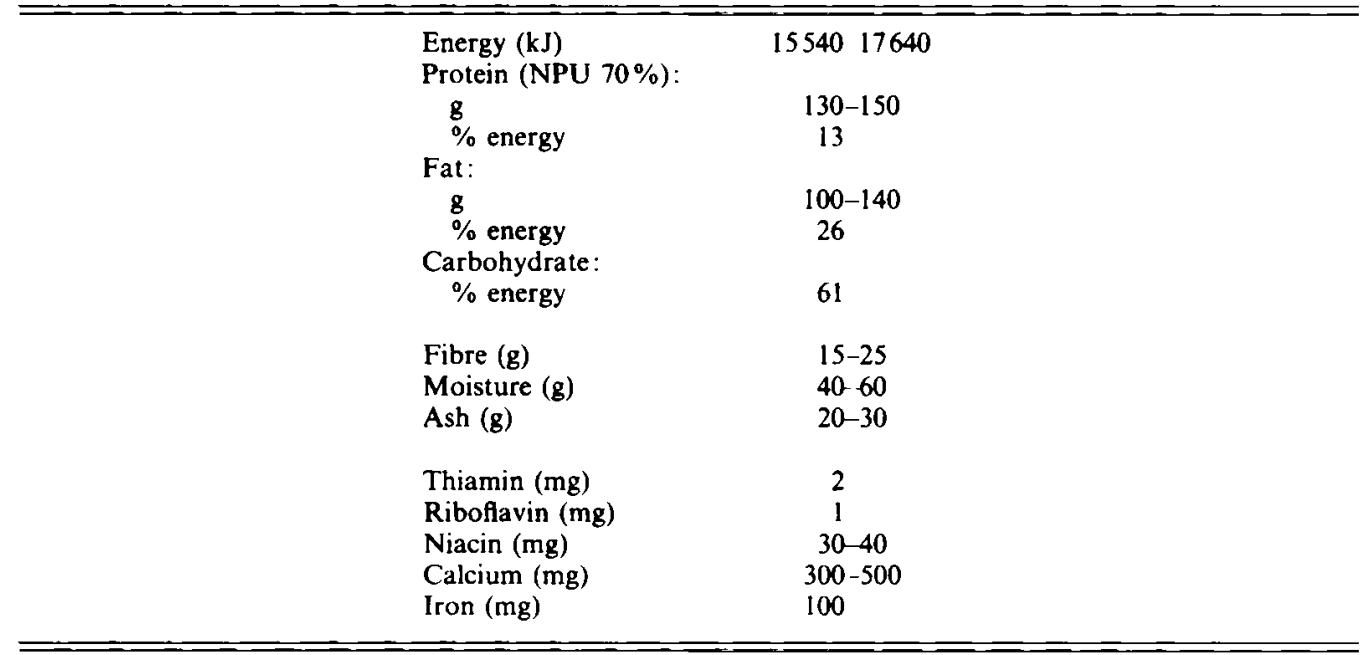

NPU, net protein utilization.

\section{METHODS OF REDUCING 'DIETARY BULK'}

Suggestions for reducing dietary bulk have centred on either altering the components of weaning foods or the processing method. Dietary bulk can be reduced by processing techniques which partly or completely break down starch molecules so that they will swell less or not at all during cooking. The processing methods suggested range from modifications or elaborations of those carried out traditionally to the use of modern techniques.

\section{Dietary components}

While in the Western world we are becoming obsessed with reducing the fat content of the diet to reduce risk of heart disease, in the Third World it is the low fat content of the diet which causes problems. This is particularly serious for young children, who once they have been taken off breast milk can have fat intakes which are very low. Indeed, the DHSS (1988) Present Day Practice in Infant Feeding warns against the use of skimmed milk for children under the age of 5 years for this reason.

Van Steenbergen et al. (1978) reported that the infants in the Machakos district of Kenya are commonly given cow's milk and this may account for the reasonably high nutritional status of the infants in this community. Table 3 shows the amounts of cow's milk in the diet and Fig. 3 shows the overall energy contributions of protein, fat and energy in infants' diets. Unfortunately cow's milk is not so readily available in many parts of the Third World.

Although fats and oils are rarely added to Third World weaning foods, their increased use has been suggested as a means of increasing gruel energy density (Dearden et al. 1980). Fat is known to alter the physical properties of starch pastes, although varying effects tend to be observed when different methods of measurement are used.

The effects of sugar and oil added to a starchy gruel can lead to a considerable improvement of energy density, with little change in apparent viscosity (Walker \& Pavitt, 


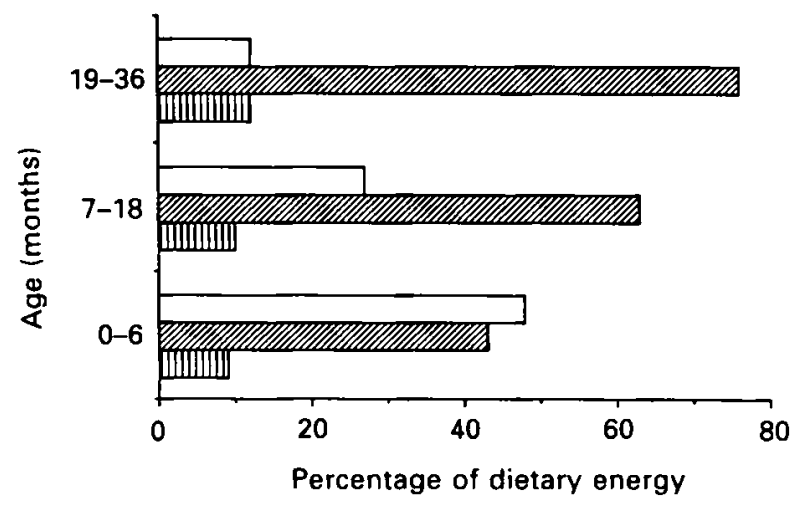

Fig. 3. Intake of energy from protein (四), carbohydrate ( $\square$ ) and fat $(\square)$ at different ages of infancy in the Machakos district of Kenya. Values from Van Steenbergen et al. (1978).

Table 6. The quantity of rice gruel $(80 \mathrm{~g}$ solids $/ l)$ which must be eaten to cover the energy requirement of a 6-month-old infant $(3220 \mathrm{~kJ} / \mathrm{d})$. From Pavitt (1987)

\begin{tabular}{lcc}
\hline \hline Type of gruel & $\begin{array}{c}\text { Quantity required to cover } \\
\text { energy needs }(\mathrm{g})\end{array}$ & $\begin{array}{c}\text { Percentage of protein } \\
\text { needs covered }\end{array}$ \\
\hline Rice & 2280 & 122 \\
Rice $+15 \mathrm{~g}$ sugar $/ 200 \mathrm{~g}$ gruel & 1210 & 65 \\
Rice $+15 \mathrm{~g}$ oil $/ 200 \mathrm{~g}$ gruel & 760 & 41 \\
\hline \hline
\end{tabular}

1989). However, although both of these substances will increase the energy density, they will jeopardize an infant's protein intake when added at high levels, as can be seen in Table 6. One solution might be to add a food ingredient which is both high in fat and protein. Peanut butter is readily available in most tropical countries and would seem to be suitable, provided it is made from good, sound seed, free from aflatoxin. However, there are no studies of the effects of this ingredient on the energy density of weaning foods.

Golden \& Ramdath (1986) warn of another potential problem of adding oils containing high levels of polyunsaturated fatty acid to weaning foods. They indicate that to give a child with kwashiorkor a food with a high level of polyunsaturated fatty acids could be hazardous, without the free radical protection of increased intake of antioxidant nutrients. They postulate that if these nutrients are lacking, polyunsaturated fatty acids would provide the substrate for the proliferation of harmful free-radical reactions, which would exacerbate the condition.

Dietary fibre may also contribute to some extent to low energy density of weaning foods. Energy contribution from dietary fibre can be low and its presence somewhat reduces the amounts of energy available from other components, especially fat. In addition, fibre has water-binding characteristics which persist through cooking. Pentosans, present in cereals, have an exceptionally high water-binding capacity. Although the benefits of a higher fibre content of the diets of adults are now widely accepted, nutritionists have been careful not to apply the same advice to infant diets. Jansen \& Harper $(1980 \mathrm{~b})$ recommended that dehulling of cereals intended for use in weaning foods for infants up to 1 year was desirable, particularly for sorghum and millet, in which digestibility of protein and starch can be reduced by the high levels of tannin contained in the testa. 


\section{Seed germination}

Traditional Third World processing methods for the preparation of weaning foods include germination of cereal and legume seeds and fermentation of flour. Desikachar (1980) found that weaning foods with a higher energy density at an acceptable apparent viscosity could be prepared from germinated seeds of legumes and cereals. Brandtzaeg et al. (1981) concluded from their studies of malted (germinated and then heat-treated) millet and sorghum that the apparent viscosity of gruels prepared from them was markedly reduced.

The effect of germination on the quality of sorghum gruels was also studied by Mosha et al. (1983). The apparent viscosity of gruels prepared from ungerminated flour with $50-100 \mathrm{~g}$ solids/ 1 ranged from 3000 to $60000 \mathrm{mPa} s$ respectively, while gruels of grain germinated for $48 \mathrm{~h}$, within the same apparent viscosity range, contained $100-250 \mathrm{~g}$ solids/1. On the assumption that apparent viscosity suitable for feeding children (unspecified age) ranged from 1000 to $3000 \mathrm{mPa}$, they concluded that the amount of flour in gruels could be increased two to three times by germinating the grain.

There is no doubt that a $48 \mathrm{~h}$ germination period greatly reduces the apparent viscosity of gruels prepared from cereals such as sorghum and that this is consistent with an increase in amylase content of the seeds from which the gruel has been prepared (Pavitt, 1987). Therefore, this practice would allow the preparation of gruels with a much higher solids content. However, in African countries, the ambient conditions will be particularly conducive to mould development, so contamination with aflatoxin during germination is a real danger. Indeed, Mosha \& Svanberg (1983) noted that mouldy seeds were present in a sample of a sorghum variety germinated in a Tanzanian village. Aflatoxin is a serious problem in the humid tropics, in particular, and there is evidence of acute aflatoxin poisoning in Kenya (Ngindu et al. 1982).

\section{Use of enzyme preparations}

Workers in India and Africa have already started to investigate a more convenient way of exploiting the enzyme activity of flour from germinated grain. Mosha \& Svanberg (1983) added enzyme-rich flour from germinated sorghum to gruels prepared from nongerminated sorghum. At a rate of addition of about $50 \mathrm{~g} / \mathrm{kg}$ total flour, the apparent viscosities of gruels prepared from different sorghum varieties were reduced from an initial range $9000-16000 \mathrm{mPa} s$ to $<1000 \mathrm{mPa}$ s within $5 \mathrm{~min}$. These workers concluded that using enzyme-rich flour to liquefy prepared gruels held more promise than using germinated flour, since it was less time-consuming. Indeed, enzyme-rich flour could be obtained in the process of local beer production. Gopaldas et al. (1987) used the same technique to reduce the apparent viscosity of thick rice gruels. They found that, although a longer germination time was required to achieve the maximum development of amylase content for the production of enzyme-rich flour, overall there was a time saving compared with the preparation of gruels from germination seeds.

The effect of enzyme treatment on various aspects of weaning food mixtures was studied by Buffa (1969). $\alpha$-Amylases of bacterial origin were used to partly break down the starches. The apparent viscosity of gruels prepared from enzyme-treated mixtures was markedly reduced and their sensory quality was reported as improved.

\section{Fermentation}

Fermentation is a traditional food preparation process used widely in Nigeria to produce their most important weaning food, ogi, from sorghum or millet (Fashakin \& Ogunsola, 1982; Dada \& Muller, 1983). Indeed, fermented sour porridge is used extensively for 
weaning infants in some parts of Africa. Mlingi (1988) showed that fermented cassava flour had a lower viscosity than the unfermented control. In addition, there is some evidence of a reduction in pathogen load during fermentation of sorghum-containing weaning foods, which is due to the reduction in $\mathrm{pH}$ (Nout et al. 1988). Mensah et al. (1988) provide evidence that it is not only the increased acidity which prevents the growth of pathogens, but also an antibiotic effect produced by the fermentation flora. Fermentation is another example of a process which offers potential to reduce the bulk and improve the nutritional values of weaning foods, but it has so far received little sound scientific study.

\section{Extrusion cooking}

The application of low-cost extrusion cooking to weaning foods has been studied by Conway et al. (1968), Jansen \& Harper (1980a) and Jansen et al. (1981). The process reduced dietary bulk by shearing starch molecules and is reported to improve palatability and digestibility of the products. Jansen et al. (1981) concluded that extruder-cooked maize-soya-bean blends resulted in gruels substantially higher in energy density than those made from raw maize-soya-bean blend.

These processing methods seemed to achieve the desired effect of reducing dietary bulk, but they are technically sophisticated and unsuitable for small-scale processing at village level.

\section{MONOTONOUS DIETS}

It has commonly been assumed that taste perception is immature in infants, like some other physiological systems, and that texture is a far more important characteristic of weaning foods, and governs acceptability. This may be so, but Kare \& Beauchamp (1985) consider that the sensory characteristics of weaning foods have been unduly overlooked. Taste primes the digestive tract for the arrival of food (in adult humans taste has been demonstrated to affect gastric and biliary function), so it is conceivable that it will affect the efficiency of food utilization.

Underwood (1985) was also concerned about poor sensory characteristics of weaning foods in the Third World. The monotony of the diet may act synergically with the consequences of repeated infections and result in chronically depressed appetite. $\mathrm{He}$ advocated that increased attention be given to providing variety in the weaning diet from at least $\mathbf{4}$ months onward.

\section{CONCLUSION}

The weaning period is a vulnerable period of life and especially so when resources are limited. Death and morbidity due to PEM in infancy continue to scourge populations in many parts of the Third World. Dietary surveys in many of these countries reveal low intakes of energy at this critical time of human development. Although some nutritionists have argued that RDA for energy for weanling infants may be set too high, intakes of many infants in the Third World are too far below international RDA to be accounted for by this alone.

If energy intakes are low, then protein is used as an energy source and not for growth and tissue repair. With most foods (except very-low-protein staples, such as cassava, plantain or sweet potato), it is not difficult to satisfy human protein requirements even in infancy if energy needs are met. This is because human beings have very low protein requirements compared with other mammalian species. Human milk contains only $6 \%$ of energy as protein (PE ratio percentage) and yet most weaning food formulations have much 
higher levels than this. Work by Axelsson et al. (1987a, b, 1988 a, b) described in the present review provides metabolic evidence of excessive protein intakes over the weaning period in infants consuming food of PE ratio percentages greater than that of human milk. When protein intake is excessive the extra protein is used for energy. While there is no suggestion that at the age of weaning excess protein is harmful to the child, aiming to provide highprotein weaning foods in the Third World may be wasteful of resources.

Weaning foods with a low energy density contribute to the development of PEM in developing countries. This problem arises because commonly-used weaning foods are prepared from starch-rich cereal flours which, when heated with water, form semi-fluid foods of a thick consistency with low solids content. As a consequence, more water may be added by mothers preparing weaning foods in order to produce food of a suitable consistency for their infants to consume, thus even further reducing the energy density.

Traditional food processing techniques offer the potential to reduce dietary bulk and, therefore, to promote increased food intake, yet have the major disadvantage of being timeconsuming. Germination (including malting) may prove to be an important technique for reducing the dietary bulk of weaning foods, but the risk of aflatoxin contamination should not be overlooked. The addition of fat in the form of peanut butter may help, although this has not been properly studied.

In the present review the main emphasis has been on ways of increasing energy density of traditional weaning foods in the Third World. This will continue to be important in the alleviation of PEM, as food intake and, therefore, nutrient intake is regulated by dietary energy. However, with the growing understanding of the role of nutrients other than energy and protein in the aetiology of PEM, it is urgent that equal attention be given to vitamin and mineral status in the future. In particular, this is needed for those nutrients involved in antioxidant activity, which are required to minimize toxic damage due to free-radical formation. As high levels of $\mathrm{Fe}$ have been implicated in the initiation of free-radical formation in kwashiorkor, the intake and availability of Fe from traditional weaning foods also needs more attention.

Research effort should be concentrated on establishing the best ways for people in the Third World to utilize their locally-available resources. Processing modifications should ideally be simple and cheap and fit into the traditional culinary and child-feeding practices of the region. More variety of weaning foods may help to increase low energy intake due to monotonous diets. However, problems need to be identified and solved at a local level. This approach would also provide local examples for much needed education programmes on weaning food preparation. PEM is not a simple nutritional disorder, but a multifactorial problem involving all aspects of a community. Therefore, although feeding during weaning is a key problem, it must be tackled in conjunction with other socio-economic efforts to promote health, good hygiene and education.

\section{REFERENCES}

Abrahamsson, L., Velarde, N. \& Hambraeus, L. (1978). The nutritional value of home-prepared and industrially produced weaning foods. Journal of Human Nutrition 32, 279. 284.

Akinyele, I. O. \& Omotola, B. D. (1986). Energy and protein intake of infants and children from the low income group of Ibadan. Nutrition Research 6, 129. 137

Anon. (1986). Breast-fed infants grow more slowly than infants fed formula and solids. Nutrition Revieu's 44, 168-169.

Anyanwu, R. C. \& Enwonwu, C. O. (1985). Impact of urbanization and socioeconomic status on infant feeding practices in Lagos, Nigeria. Food and Nutrition Bulletin 7 (1), 3337.

Axelsson, I., Borulf, S., Abildskov, K., Heird, W. \& Räihä, N. C. R. (1988a). Protein and energy intake during weaning. III. Effects on plasma amino acids. Acta Paediatrica Scandinavica 77, 42-48. 
Axelsson, I., Borulf, S. \& Räihä, N. C. R. (1987a). Protein intake during weaning. II. Metabolic responses. Acta Paediatrica Scandinavica 76, 457-462.

Axelsson, I., Borulf, S., Righard, L. \& Räihä, N. C. R. (1987 b). Protein and energy intake during weaning. I. Effects on growth. Acta Paediatrica Scandinavica 76, 321 -327.

Axelsson, I. E., Jakobsson, I. \& Räihä, N. C. R. (1988b). Formula with reduced protein content : effects on growth and protein metabolism during weaning. Pediatric Research 24, $297-301$.

Barrell, R. A. E. \& Rowland, M. G. M. (1979). The relationship between rainfall and well water pollution in a West African (Gambian) village. Journal of Hygiene 83, 143-150.

Black, R. E., Brown, K. H., Becker, S., Alim, A. R. \& Merson, M. H. (1981). Contamination of weaning foods and transmission of enterotoxigenic Escherichia coli diarrhoea in children in rural Bangladesh. Transactions of the Royal Society of Tropical Medicine and Hygiene 76, 259264.

Black, R. E., de Romana, G. L., Brown, K. H., Bravo, N., Bazalar, O. G. \& Kanashiro, H. C. (1989). Incidence and etiology of infantile diarrhea and major routes of transmission in Huascar, Peru. American Journal of Epidemiology 129, 785-799.

Brandtzaeg, B., Malleshi, N. G., Svanberg, U., Desikachar, H. S. B. \& Mellander, O. (1981). Dietary bulk as a limiting factor for nutrient intake with special reference to the feeding of pre-school children. III. Studies of malted flour from ragi, sorghum and green gram. Journal of Tropical Pediatrics 27, 184-189.

Buffa, A. (1969). Enzyme treated weaning food mixtures. Assignment Children 9, 107- 127.

Cameron, M. \& Hofvander, Y. (1983). Manual on Feeding Infants and Young Children. 2nd ed. Oxford: Oxford University Press.

Chesters, J. K. \& Arthur, J. R. (1988). Early biochemical defects caused by dietary trace element deficiencies. Nutrition Research Reviews 1, 39-56.

Conway, H. F., Lancaster, E. B. \& Bookwalter, G. N. (1968). How extrusion cooking varies product properties. Food Engineering 40 (11), 102-104.

Corring, T., Aumaitre, A. \& Durand, G. (1978). Development of digestive enzymes in the piglet from birth to 8 weeks. I. Pancreas and pancreatic enzymes. Nutrition and Metabolism 22, 231-243.

Corring, T., Lebas, F. \& Courtot, D. (1972). [Factors influencing changes in pancreatic enzyme secretion in the rabbit from birth to 6 weeks.] Annales de Biologie Animale, Biochimie, Biophysique 12, 221-231.

Dada, L. O. \& Muller, H. G. (1983). The fate of aflatoxin $B_{1}$ in the production of ogi, a Nigerian fermented sorghum porridge. Journal of Cereal Science 1, 63-70.

Dagnelie, P. C., van Staveren, W. A., Vergote, F. J. V. R. A., Burema, J., van't Hoft, M. A., van Klaveren, J. D. \& Hautvast, J. G. A. J. (1989). Nutritional status of infants aged 4 to 18 months on macrobiotic diets and matched omnivorous control infants: a population based mixed-longitudinal study. II. Growth and psychomotor development. European Journal of Clinical Nutrition 43, 325 338.

Dearden, C., Harman, P. \& Morley, D. (1980). Eating more fats and oils as a step towards overcoming malnutrition. Tropical Doctor 10, 137-142.

Del Valle, F. R., Villanueva, H., Reyes-Govea, J., Escobedo, M., Bourges, H., Ponce, J. \& Munoz, M. J. (1981). Development, evaluation and industrial production of a powdered soy-oats infant formula using a low-cost extruder. Journal of Food Science 46, 192-197.

Department of Health and Social Security (1988). Present Day Practice in Infant Feeding: Third Report. London: H.M.Stationery Office (Report on Health and Social Subjects no. 32).

Desikachar, H. S. R. (1980). Development of weaning foods with high caloric density and low hot-paste viscosity using traditional technologies. Food and Nutrition Bulletin 2 (4), 21-23.

Dettwyler, K. A. (1986). Infant feeding in Mali, West Africa : variations in belief and practice. Social Science and Medicine 23, 651664

Dettwyler, K. A. (1987). Breastfeeding and weaning in Mali: cultural context and hard data. Social Science and Medicine 24, 633644 .

Dimond, H. J. \& Ashworth. A. (1987). Infant feeding practices in Kenya, Mexico and Malaysia. The rarity of the exclusively breast-fed infant. Human Nutrition: Applied Nutrition 41A, 51-64.

Elegbe. I. A. \& Ojofeitimi, E. O. (1984). Early initiation of weaning food and proliferation of bacteria in Nigerian infants. Clinical Pediatrics 23, 261-264.

Fashakin, J. B. \& Ogunsola, F. (1982). The utilization of local foods in the formulation of weaning foods. Journal of Tropical Pediatrics 28, 93--96.

Food and Agriculture Organization/World Health Organization (1973). Energy and Protein Requirements. Rome: FAO. (FAO Nutrition Meetings Report Series no. 52).

Food and Agriculture Organization/World Health Organization/United Nations University (1985). Energy and Protein Requirements. Geneva: WHO. (WHO Technical Report Series no. 724).

Golden, M. H. N. \& Ramdath, D. (1986). Free radicals in the pathogenesis of kwashiorkor. In Proceedings of the XIII International Congress of Nutrition - 1985. [T. G. Taylor and N. K. Jenkins, editors]. London: John Libbey.

Gopalan, G. (1968). Kwashiorkor and marasmus: evolution and distinguishing features. In Calorie Deficiencies and Protein Deficiencies, pp. 49.58 [R. A. McCance and E. M. Widdowson, editors]. London: Churchill Livingstone. 
Gopaldas, T., Mehta, P., Patil, A. \& Gandhi, H. (1987). Studies on reduction in viscosity of thick rice gruels with small quantities of an amylase-rich cereal malt. Food and Nutrition Bulletin 8 (4), $42-47$.

Hambidge, K. M. (1986). Zinc deficiency in the weanling - how important? Acra Paediatrica Scandinavica Suppl. $323,5258$.

Hansen, L. P. \& You, G. (1982). A biological evaluation of high-protein rice flour for infants and young children. Nutrition Reports International 26, 1087-1094.

Hellstrom, A., Hermansson, A., Karlsson, A., Ljungqvist, B., Mellander, O. \& Svanberg, U. (1981). Dietary bulk as a limiting factor for nutrient intake - with special reference to the feeding of pre-school children. II Consistency as related to dietary bulk - a model study. Journal of Tropical Pediatrics 27, 127-135.

Hoyle, B., Yunus, M. \& Chen, L. C. (1980). Breast-feeding and food intake among children with acute diarrheal disease. American Journal of Clinical Nutrition 33, 2365-2371.

Hudson, G. J., John, P. M. V. \& Paul, A. A. (1980). Variation in the composition of Gambian foods: the importance of water in relation to energy and protein content. Ecology of Food and Nutrition 10, 9-17.

Jansen, G. R. \& Harper, J. M. (1980a). Application of low-cost extrusion cooking to weaning foods in feeding programmes. Part L. Food and Nutrition 6 (1), 2-9.

Jansen, G. R. \& Harper, J. M. (1980 b). Application of low-cost extrusion cooking to weaning foods in feeding programmes. Part 2. Food and Nutrition 6 (2), 15-23.

Jansen, G. R., O'Deen, L., Tribelhorn, R. E. \& Harper, J. M. (1981). The calorie densities of gruels made from extruded corn-soy blends. Food and Nutrition Bulletin 3 (1), 39-44.

Jones, V. M. (1987). Current infant weaning practices within the Bangladeshi community in the London Borough of Tower Hamlets. Human Nutrition: Applied Nutrition 41, 349-352.

Kare, M. R. \& Beauchamp, G. K. (1985). The role of taste in the infant diet. American Journal of Clinical Nutrition 41, 418-422.

Lebenthal, E. (1985). Impact of digestion and absorption in the weaning period on infant feeding practices. Pediatrics 75, 207-213.

Ljungqvist, B. G., Mellander, O. \& Svanberg, U. S.-O. (1981). Dietary bulk as a limiting factor for nutrient intake in pre-school children. Journal of Tropical Pediatrics 27, 68-73.

McCrae, J. E. \& Paul, A. A. (1979). Food of Rural Gambia. Cambridge: MRC Dunn Nutrition Unit.

Mensah, P. P. A., Tomkins, A. M., Drasar, B. S. \& Harrison, T. J. (1988). Effect of fermentation of Ghanaian maize dough on the survival and proliferation of 4 strains of Shigella flexneri. Transactions of the Royal Society of Tropical Medicine and Hygiene 82, 635-636.

Milla, P. J. (1986). The weanling's gut. Acta Paediatrica Scandinavica Suppl. 323, 5-13.

Mlingi, N. L. V. (1988). Reducing dietary bulk in cassava-based weaning foods by fermentation. In Proceedings of a Workshop on Improving Child Feeding in Eastern and Southern Africa. Household-level Food Technology, Nairobi, Kenya, 1987.

Morcos, S. R., Said, A. K., Gabrial, G. N. \& Hady, N. A. E. (1983). Supplementary and weaning foods for the Egyptian child. Nahrung 27, 295-304.

Mosha, A. C. \& Svanberg, U. (1983). Preparation of weaning food with high nutrient density using flour of germinated cereals. Food and Nutrition Bulletin 5 (2), 10-14.

Mosha, A. C., Svanberg, U., Lieden, S. A., Ljungqvist, B. \& Haq, A. (1983). Effects of germination on the food and nutritional value of sorghum. In Research in Food Science and Nutrition vol. 1, The Production, Preservation and Processing of Food. pp. 18-19 [J. V. McLoughlin and B. M. McKenna, editors]. Dublin: Boole Press. Proceedings of the VIth International Congress of Food Science and Technology.

Nattress, L. A., Mehta, T., Mitchell, M. E. \& Finney, P. L. (1987). Formulation and nutritive value of weaning food from germinated food grains. Nutrition Research 7, 1309-1320.

Ngindu, A., Johnson, B. K., Kenya, P. R., Ngira, J. A., Ocheng, D. M., Nandwa, H., Omondi, T. N., Jansen, A. J., Ngare, W., Kaviti, J. N., Gatei, D.\& Siongok, R. A. (1982). Outbreak of acute hepatitis caused by afiatoxin poisoning in Kenya. Lancet $\mathbf{i}, 13461348$.

Nout, M. J. R., Hautvast, J. G. A. J., van der Haar, F., Marks, W. E. W. \& Rombouts, F. M. (1988). Formulation and microbiological safety of cereal-based weaning foods. In Proceedings of a Workshop on Improving Child Feeding in Eastern and Southern Africa. Household-level Food Technology, Nairobi, Kenya, 1987.

Nutrition Standing Committee of the British Paediatric Association (1988). Vegetarian weaning. Archives of Disease in Childhood 63, 1286-1292.

Pavitt, F. (1987). Energy density and consistency of traditional African weaning foods. PhD Thesis, University of Reading.

Persson, L. A., Johansson, E. \& Samuelson, G. (1984). Dietary intake of weaned infants in a Swedish community. Human Nutrition: Applied Nutrition 38A, 247-254.

Pigott, J. \& Kolasa, K. (1983). Infant feeding practices and beliefs in one community in the Sierra of rural Ecuador: a prevalence study. Archivos Latinoamericanos de Nutricion 33, 126-138.

Prasannappa, G. \& Jagannath, K. S. (1985). A nutritious food supplement for feeding programme. Nutrition Reports International 31, 191-197.

Ramdath, D. D. \& Golden, M. H. N. (1989). Non-haematological aspects of iron nutrition. Nutrition Research Reviews 2, 29-49. 
Rowland, M. G. M. (1986). The weanling's dilemma: are we making progress? Acta Paediatrica Scandinavica Suppl. 323, 33-42.

Rowland, M. G. M., Barrell, R. A. E. \& Whitehead, R. G. (1978). Bacterial contamination in traditional Gambian weanings foods. Lancet i, 136-138.

Rowland, M. G. M., Cole, T. J. \& Whitehead, R. G. (1977). A quantitative study into the role of infection in determining nutritional status in Gambian village children. British Journal of Nutrition 37, 441450.

Royal Tropical Institute, Amsterdam (1987). Weaning Food-A New Approach to Small-scale Weaning Food Production from Indigenous Raw Materials in Tropical Countries, 2nd ed. Amsterdam. RTI, Rural Development Programme, Nutrition and Agrotechnology Section.

Rutishauser, I. H. E. \& Frood, J. D. L. (1973). The effect of a traditional low-fat diet on energy and protein intake, serum albumin concentration and body-weight in Ugandan preschool children. British Journal of Nutrition 29, 261-268.

Tomkins, A. \& Hussey, G. (1989). Vitamin A, immunity and infection. Nutrition Research Reviews 2, 17-28.

Underwood, B. A. (1985). Weaning practices in deprived environments-the weaning dilemma. Pediatrics 75 , 194-198.

United Nations (1987). First Report on the World Nutrition Situation. Report of the Administrative Committee on Coordination-Subcommittee on Nutrition $(A C C / S C N)$. Rome: FAO.

Vaidehi, M. P. \& Gowda, A. R. (1981). Protein quality of extrusion cooked cereal based weaning foods in Wistar strain albino rats. Nutrition Reports International 23, 363370.

Van Steenbergen, W. M., Kusin, J. A., Voorhoeve, A. M. \& Jansen, A. A. J. (1978). Machakos Project studies: Agents affecting health of mother and child in a rural area of Kenya. IX. Food intake, feeding habits and nutritional state of the Akamba infant and toddler. Tropical and Geographical Medicine 30, $505_{5} 522$.

Vargas, E., Blanco, A., Lastreto, C. \& Roman, A. V. (1985). [Biological evaluation of an infant food based on soya, rice and bananas.] Archivos Latinoamericanos de Nutricion 35, 90-104.

Victora, C. G., Smith, P. G., Vaughan, J. P., Nobre, L. C., Lombardi, C., Teixeira, A. M. B., Fuchs, S. M. C., Moreira, L. B., Gigante, L. P. \& Barros, F. C. (1987). Evidence for protection by breast-feeding against infant deaths from infectious diseases in Brazil. Lancet $\mathbf{i i ,}$ 319-322.

Victora, C. G., Vaughan, J. P., Martines, J. C. \& Barcelos, L. B. (1984). Is prolonged breast-feeding associated with malnutrition? American Journal of Clinical Nutrition 39, 307-314.

Walker, A. F. \& Pavitt, F. (1989). Energy density of Third World weaning foods. BNF (British Nutrition Foundation) Nutrition Bulletin 14, 88-101.

Waterlow, J. C. \& Payne, P. R. (1975). The protein gap. Nature 258, 113-117.

Waterlow, J. C. \& Thomson, A. M. (1979). Observations on the adequacy of breast-feeding. Lancet ii, $238-242$.

Webb, G. P. (1989). The significance of protein in human nutrition. Journal of Biological Education 23, $119-124$.

Whichelow, M. J. (1982). Factors associated with the duration of breast feeding in a privileged society. Early Human Development 7, 273-280.

Whitehead, R. G. (1985a). The human weaning process. Pediatrics 75 Suppl., 189-193.

Whitehead, R. G. (1985 b). Infant physiology, nutritional requirements, and lactational adequacy. American Journal of Clinical Nutrition 41, 447-458.

Whitehead, R. G. (1989). Food safety in the United Kingdom-lessons from the Third World. In How Safe is Our Food? pp. 9-26. [M. Ashwell, editor]. London: British Nutrition Foundation. (BNF (British Nutrition Foundation Nutrition) Bulletin 14, Suppl. 1.). 